\title{
O COLÉGIO BRASILEIRO DE CIRURGIÕES E A RESPONSABILIDADE CIVIL
}

\author{
THE BRAZILIAN COLLEGE OF SURGEONS AND THE DAMAGE LIABILITY
}

\author{
Dr. Roberto Saad Junior \\ Presidente do Colégio Brasileiro de Cirurgiões
}

A Classe Médica está sujeita a responder em dois Tribunais: Justiça Comum e Conselho de Medicina. E mais, na Justiça Comum poderá responder por responsabilidade civil médica e responsabilidade penal.

O Conselho de Medicina, órgão que fiscaliza a profissão, pode iniciar um processo ético profissional, a partir de denúncia formulada por um Conselheiro, pelo próprio doente ou ainda através de Comissão de Ética Médica. É o Código de Ética Médica que rege o julgamento. É instaurada uma sindicância, quando se avalia se existem elementos suficientes para que se abra um processo ético profissional. Uma vez aberto um processo, este terminará com absolvição ou condenação do médico acusado. Conforme a gravidade do "erro médico", as condenações variam: advertência confidencial, censura confidencial, censura publica, suspensão até 30 dias e cassação do diploma médico.

O Colégio Brasileiro de Cirurgiões apesar de entender que o julgamento do Conselho de Medicina é justo e a pena imposta ao réu é isenta de qualquer outro sentimento, senão o da justiça. Nesta situação, estão envolvidos médicos competentes (julgadores) que possuem discernimento claro, entre o erro médico verdadeiro e o chamado erro profissional (complicações, resposta inesperada do organismo etc.).

No processo criminal, é na Delegacia que tudo começa. É realizado um boletim de ocorrência (BO) e daí o inquérito policial. O delegado de polícia julgará se é caso ou não de crime. Caso haja indícios de crime, o julgamento se fará na Justiça Criminal, sob o manto do Código Penal; nesta situação, o acusador será o Promotor Público e, havendo culpa, as condenações possíveis serão: penas privativas de liberdade, prestação de serviço à comunidade e multas.

O Colégio Brasileiro de Cirurgiões entende que, muito embora alguns julgamentos poderão ser falhos em decorrência da definição correta do que seja realmente um "erro médico", não teme este Tribunal. São poucas as ocorrências e a experiência tem mostrado que são os casos que beiram à criminalidade, aqueles que aqui encontram guarida.

No processo civil, o advogado do autor (doente) é o acusador. Em se constatando "erro médico", requer o advogado indenização por danos morais e materiais. Os Códigos Civil e do Consumidor são invocados para nortear o julgamento. No caso de "Culpa", fica a critério do juiz estabelecer um montante em dinheiro que o réu deverá pagar ao autor.

O Colégio Brasileiro de Cirurgiões entende que, neste Fórum, muito há que se temer. Inicialmente é importante ressaltar que a pena a ser aplicada é pagamento em dinheiro para o autor. Este fato é um grande incentivador de proces- sos. Tanto o doente como o seu advogado (não todos) acreditam que ficarão ricos. Normalmente o autor consegue a chamada justiça gratuita e, com este instrumento, o doente pede valores altos, porque nada tem a perder. Se ganhar o processo, leva uma soma razoável de dinheiro, caso contrário, nada perde, isto é, pode arriscar a vontade, pois nunca perderá. $\mathrm{O}$ Julgador, via de regra, considera o doente (acusador) hipossuficiente e vítima, o que de certa forma deixa o médico em desvantagem. Não bastassem estes fatos, há ainda que se discutir sobre a definição de "erro médico". O doente afirma que o médico errou, o advogado procura por todos os meios provar estes "erros" e o juiz, como se comporta? A infeliz verdade é reconhecer que o Julgador não estudou medicina, pior do que isto: não sabe diferenciar um "erro verdadeiro" de um "erro profissional”, como então julgar?

\section{Vamos a um exemplo:}

Supondo que um indivíduo esteja com a perna amarrada em uma linha de trem. O trem vem chegando e o maquinista tem duas opções, pois ali há um desvio: a primeira é seguir o caminho que não passa sobre o trilho onde está amarrado o pobre indivíduo; a segunda, é exatamente passar sobre o infeliz. Um observador (médico) verifica que se o maquinista optar pela primeira possibilidade nada acontecerá com o homem da nossa história; caso escolha a segunda opção, ele (doente) morrerá. Qual a conduta que o observador deverá escolher?

1 - Amputar a perna do "doente" para livrá-lo da possível morte?

2 - Deixar o "doente" à própria sorte?

Caso o observador (médico) escolha por amputar a perna do cidadão e retirá-lo do perigo e o maquinista passe justamente onde estava localizado a vítima, todos gritaremos que o observador é um GRANDE HERÓI, pois salvou o homem. Mas se o observador (médico) amputou a perna do infeliz e o maquinista optou pelo caminho no qual ele não estava amarrado, de Herói o nosso observador passa a BANDIDO!

Esta história evidencia de forma dramática o que pode estar ocorrendo nos julgamentos dos assim chamados "erros médicos", talvez enganos e injustiças!

A problemática de caracterização do Erro em Medicina não se restringe às fronteiras da Ciência, mas as extravasa para o domínio da arte e do imponderável.

O Colégio Brasileiro de Cirurgiões não está inerte quanto a estes fatos e vem trabalhando junto à Frente Parlamentar da Saúde e outras Instituições com o objetivo de resgatar estas verdades. 